\title{
SPATIAL ANALYSIS APPROACH RELATED TO THE RELATIONSHIP BETWEEN PROXIMITY AND SECURITY PERCEPTION IN ENCOURAGEMENT OF PUBLIC SPACE PARK USE: THE CASE STUDY OF KALBU PALEM PARK (BANDUNG, INDONESIA)
}

\author{
Malik ANDY', Akbar ROOS ${ }^{1}$, Maryati SRI ${ }^{1}$, Indradjati PETRUS
}

DOI : 10.21163/GT_2020.151.18

\begin{abstract}
:
The existence of the park must provide a sense of security for its users in social interaction so as to increase public awareness through their relationship with the urban environment in creating sustainable urban life. From previous studies, the purpose of this study is to elaborate proximity (geography) with security perceptions (as part of environmental psychology) in encouragement of public space use. There is a debate about the aspects of proximity and encouragement to use the park, but related to the perception of security is still limited, especially in Indonesia. Proximity is much discussed in the science of geography, while the security perception in this study is an important entry point in park planning which plays an important role in strengthening urban communities. People perceptions might be indicated as one of the most interesting parts of human-geographic researches. This research uses descriptive quantitative method that aims to explain the extent of the encouragement of park use based on security perceptions through the stages of spatial mapping, data collection and through questionnaires. The spatial analysis conducted in this study is to calculate analysis through the proximity between the locations of the house from the respondents to the park with the use of transportation modes through Shortest Path Trace (SPT) and Security Perception (SP) method of spatial analysis spatial mapping using ArcGIS 10.3 and compare it with the answers from respondents related to security perceptions with the proximity of the park location. The results of this study indicate that proximity has a low significance on security perceptions of the respondents' that there is a weak link between proximity and park usage based on security perceptions in encouragement use of park.
\end{abstract}

Key-words: Proximity, Security Perception, Kalbu Palem Park, Sekeloa Urban Village, Bandung.

\section{INTRODUCTION}

Various studies have shown the park is a representation of the initial identity of public place as a place that is freely accessed by various communities without any profit motive as a space for interaction, negotiation, sharing information from various community characteristics that will support the survival of urban communities (Shaftoe, 2009; Low, 2010). Social aspect is defined as the relationship between individuals (Fujiki and Renalds, 2019). Related to its social function, the park is a location where people from various backgrounds, ethnicities and genders gather to carry out various social activities (Roberts, 2014). According to Byrne and Wolch (2009) parks play a role in making the lives of urban communities more quality, more "healthier", more moral, more socially-minded, wiser, and

\footnotetext{
${ }^{1}$ Institute Technology of Bandung, Indonesia,andymalik_80@yahoo.com,rakbar@pl.itb.ac.id , smaryati@pl.itb.ac.id,natalivan@sappk.itb.ac.id
} 
smarter (strengthening the urban communities). This is in line with other studies that show that park use can reduce social problems (including anti-social behavior), as a social bond between urban community groups and a space that can protect the rights of user groups in the learning process of living together as a community through interaction and information sharing in an environment (Holland et al., 2007; Roberts, N, 2014). Thus the use of parks by the community in relation to their social functions plays an important role in raising public awareness about their relationship with the natural environment so as to create sustainable urban life.

Based on the previous discussion related to social functions, it turns out that the park has a problem in terms of its use by the community, one of the aspects that is influential in building a user base in improving the quality of the park as part of public space is related to the aspect of proximity (CABE, 2005; Mowen \& Confer, 2007; Roberts, 2014). Actually the relationship between proximity to the encouragement of park use has been examined in several previous studies including geography and environmental planning. The results of the study show that shorter proximities are very important to build a strong user base. Hanan (2013) shows park visits are influenced by several factors one of them is park location that is easily accessible that provides a sense of security and comfort for its users (allows people to carry out social interactions). Ilmiajayanti and Dewi (2015) show that one of the factors that has an influence in increasing the time of social interaction in the park is the accessibility of park users. Annerstedt, et al. (2012) mentioned that one of the variables that determine park use and activities is proximity. McCormack, et al. (2014) also define that proximity are important attributes to encourage park use. In contrast to Gamal's (2010) statement which explains the pattern of park used no longer based on the proximity but on the ease of access to information and the similarity of interests. From these results it turns out that research that looks at the relationship between proximity and the encouragement of park use based on security perceptions in Indonesia is still limited. It is hoped that this research will be carried out to supplement new empirical information that is practically useful for public space park planning in Indonesia.

In this research, perception in the realm of environmental planning and geography becomes an entry point in understanding complex of human aspects. People perceptions might be indicated as one of the most interesting parts of human-geographic researches (Martinát, et al., 2019). By accommodating people participation in urban public space such as park in this research will develop healthy communities and the equity of economic, social and, environmental aspects (Soemardiono, et al., 2019). With this, perception provides a basis in understanding the condition of society in predicting social characteristics and activities as well as people's acceptance and views of public spaces (parks). There is still debate, criticism, in encouraging the use of parks that can accommodate people's sense of security is an indication of the gap between planners and the community. Perception is one of the factors driving the formation of behavior in the environment (Blobaum and Hunecke, 2005 in Fitri, 2018). According to Blobaum and Hunecke (2005) in their research related to psychological and socio-demographic aspects, security perception is an important factor in public spaces (parks) that is influenced by physical features and design variables on security. Security Safety perception is also a psychological state which is an empirical and sensory experience and process of an individual towards the environment in which he lives, both social environment, built environment or natural environment (free from danger, free from insecurity and free from fear) (Fitri, 2018). Planner's perceptions cannot fully represent the views of the community because planners often do not have in-depth information on public spaces (Fitri, 2018). 
Pugaslis (2009) states the role of planners in urban public spatial planning tendencies in visual aspects, on the contrary the user's perception of the community itself is more emphasized on aspects of social value and cultural experience. Therefore Based on this research, community participation is needed in contributing to provide input on how their security perceptions of the existence of the park.

Therefore, the purpose of this research is to elaborate aspects of proximity and aspects of security perception in encouraging the use of public space (case study of park). focus of this research is related to the proximity and the use of park as social function based on the security perceptions. Some considerations regarding this can be traced to the theory of hierarchy of need which shows that the need for security is a basic representation of human needs that are free from danger, fear and insecurity. According to Carmona, et al. (2003), the success of public spaces (parks) depends on their ability to create a sense of security in the community, it means that the sense of security that is presented by public space to improve the quality of life of the community is an important goal that needs to be considered in the planning process and designing urban public spaces to overcome social threats such as conflicts and crime.

\section{STUDY AREA AND DATA}

The location of the park which is the study area is Kalbu Palem Park, this park is an active and conducive park (safe) in the middle of the location of residential settlements in RW 13 Sekeloa urban village (25,699 people in 2018), Coblong sub-district, Bandung, West Java Province, Indonesia which was inaugurated on January 31, 2018 with area of $485 \mathrm{~m}^{2}$. From various spatial development policy directives in Coblong sub-district, it is stated that this area requires intensive control regarding the use of existing land, especially for community settlements. Coblong sub-district has the potential to develop in other zones such as education, trade, public service facilities, green open space.

\section{METHODOLOGY}

\subsection{Quantitative approach through spatial analysis and descriptive analysis methods in research}

In this study data analysis will be performed using quantitative methods, namely spatial and descriptive analysis methods. The spatial analysis method in question is a method based on the data collection of community locations from the house to the park that is transformed through Shortest Path Trace (SPT) and Security Perception (SP) method of spatial analysis mapping using the ArcGIS 10.6 application (Handayani et al., 2005). GIS applications are commonly used for spatial analyses in the engineering and environmental fields (Nistor et al., 2019). Next, the descriptive method is a statistical technique that functions to see an overview of each variable examined in this case through questions related to how the security perception of the community is related to the proximity to the park. According to Creswell (2009), quantitative research is a method for testing certain theories by examining the relationships between variables accompanied by assumptions to prevent bias, control alternative explanations, be able to generalize and re-apply their findings. Although this research is large scale, contact with the community is faster than qualitative research. The stages of the research are shown in the figure below. 


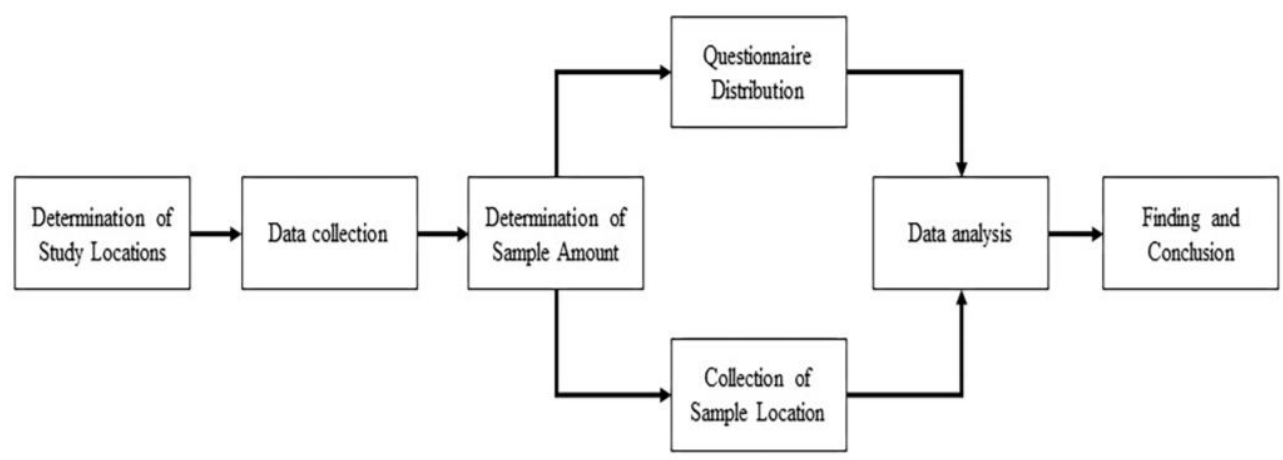

Fig. 1. Flowchart of research work (Source: authors).

The main characteristics of Geographic Information System is the ability to analyze systems such as statistical analysis and overlays called analysis spatial namely by adding the dimension 'space' or geography. Spatial analysis is done by overlaying two maps which then produce a new map analysis result. Spatial Analysis Process includes creating buffers around points, lines and areas (polygons), analyzing maps with points, lines and areas that are overlaid using the intersection, union, identity, delete, and clip. The working procedures of spatial geographic system analysis can be seen in Fig. 2 below:

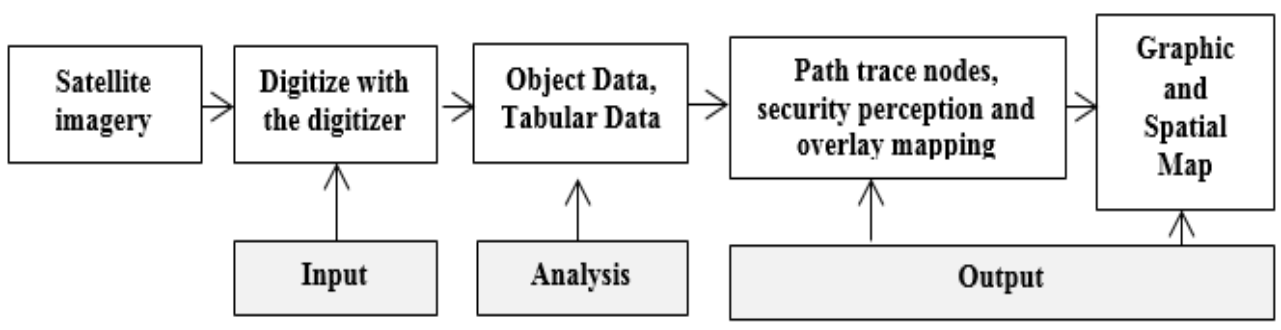

Fig. 2. The working procedures of spatial geographic system analysis (Source: authors).

Descriptive method includes an overview related to the profile of respondents as well as the main variables of the study. The question for the respondents is whether proximity affects respondents security perceptions in encouragement of park use ?. The question asked was whether the existence of the proximity to the park location made them (community in Sekeloa, urban village) feel unsecure using the park. For categorical data, the descriptive method used is the frequency value (f) and percentage (\%). As for numerical data, the descriptive method used is the average value (mean), standard deviation (standard deviation), minimum value and maximum value. For variables with a Likert scale of 5 categories, the average value is calculated and then classified into five categories according to the number of alternative answer categories. The categorization of scores is based on standard rules by dividing the score range $(5-1=4)$ into five categories with the same interval $(4 / 5=0.80)$ so that the guidelines for interpretation of average scores are obtained as follows: 
Table 1.

Guidelines for interpretation of the average score.

\begin{tabular}{|c|c|c|}
\hline $\begin{array}{c}\text { Score Interval } \\
\text { Average }\end{array}$ & Interpretation & Code \\
\hline $4,21-5,00$ & Always / very important / very high & 5 \\
\hline $3,41-4,20$ & Frequent / important / high & 4 \\
\hline $2,61-3,40$ & Sometimes / quite important / moderate & 3 \\
\hline $1,81-2,60$ & Rarely / unimportant / low & 2 \\
\hline $1,00-1,80$ & Never / very unimportant / very low & 1 \\
\hline
\end{tabular}

(Source: authors)

For the use of the questionnaire, this study uses a closed ended questionnaire, this is necessarily done to explore perceptions of park use and the impact caused by technology. For variables on filling the questionnaire using a Likert scale of 5 categories with a scale of 5 (highest) to scale 1 (lowest). This quantitative research is used because the research process carried out is based on the synthesis of theories that previously existed. This research will later explain the causes of social phenomena through objective measurement and numerical analysis (statistics). This research uses hypothesis verification to answer the problem formulation. The use of both descriptive and inference statistical analysis also adds to the characteristics that this study uses quantitative methods as the main method (Sugiyono, 2010).

\subsection{Descriptive analysis in explaining the relationship between proximity and the encouragement of park use based on community security perceptions}

The respondents sampling method used in this study was purposive sampling. This method was chosen by looking at the sample used is the user community around the park location. In this case the population used is limited population where not all populations within the coverage radius are sampled in the study. The purpose of the sample and population is as a source of data and as a tool to generalize the characteristics of relationships in proving hypotheses or propositions that represent populations. The sampling time is from July 2019 to October 2019.

The determination of frame samples using the Slovin formula:

Information:

$$
n=\frac{N}{1+N \times e^{2}}
$$

$n$ : number of samples

$\mathrm{N}$ : Total population

e: error tolerance limit used (error tolerance 5\%)

The Slovin formula is used when the population in the study area is known by the unit of analysis is individuals who are in settlements around the park location (Sevilla et al., 2007). Based on the calculation results, the number of respondents who filled out the questionnaire was 411 respondents who were residents of Sekeloa Urban Village and were also the visitors of Kalbu Palem Park. For the use of the questionnaire, this study uses a closed ended questionnaire, this is necessarily done to explore perceptions of park use and the impact caused by technology. For variables on filling the questionnaire using a Likert scale of 5 categories with a scale of 5 (highest) to scale 1 (lowest) (see Table 1). This quantitative research is used because the research process carried out is based on the synthesis of theories that previously existed. 


\section{RESULTS AND DISCUSSIONS}

The proximity based on the distance between layers using the Shortest Path Trace (SPT) method, which analyzes to find the shortest distance from two locations using the Security Perception (SP) method, which is to know the position of the distance of a point in the same direction within a certain radius. The results of the spatial mapping related to the proximity and mode used by the community from the house to the location of the first park, the Kalbu Palem park (see Fig. 3). The location point of the house shown is the result of data collection on 411 respondents in 9 hamlets (Hamlet 1 through 4 and Hamlet 11 through -15) in Sekeloa urban village.

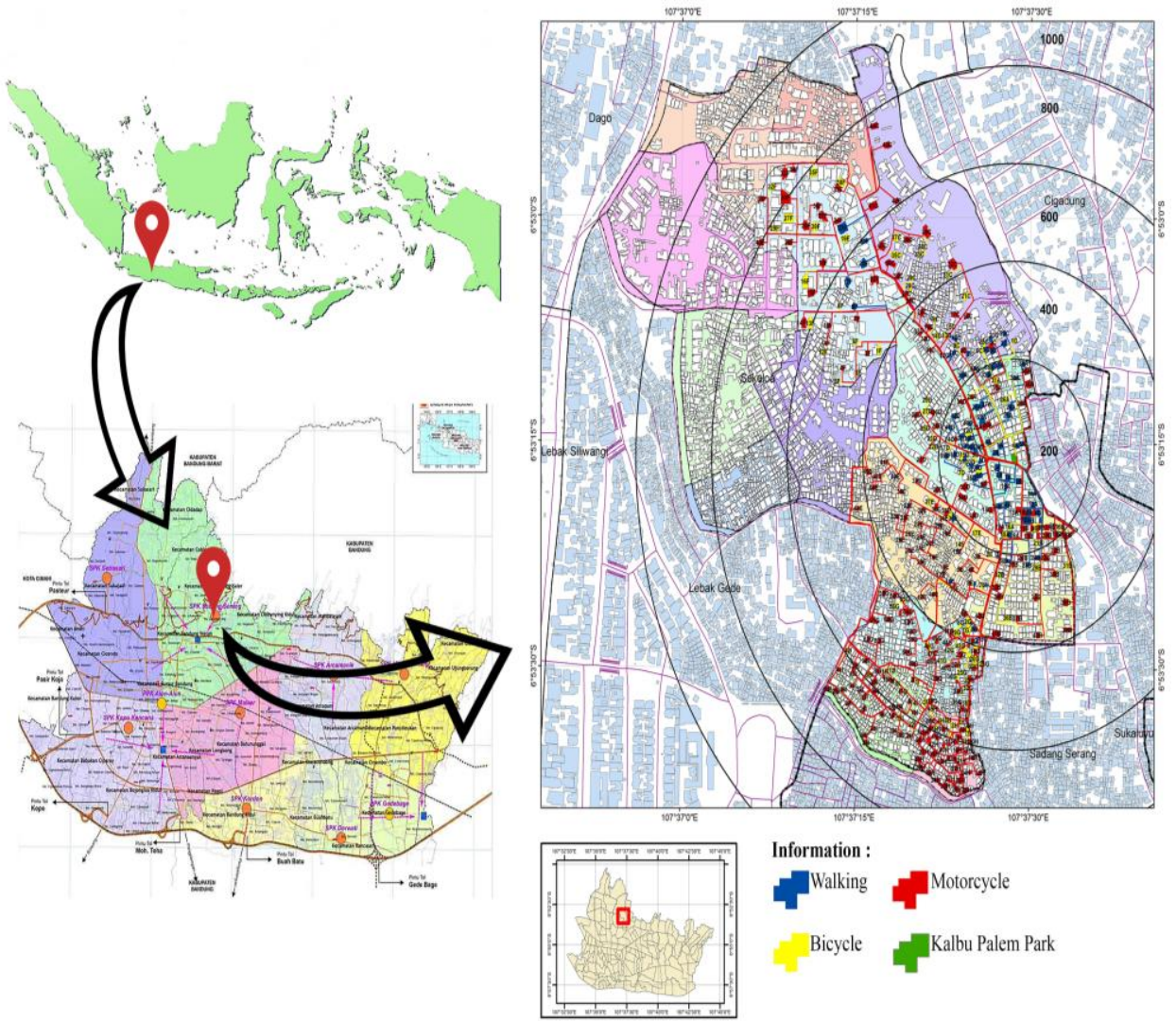

Fig. 3. Map of study location boundaries in Sekeloa urban village, Bandung City, Indonesia, based on the radius of coverage and mode used by respondents to the park (Source: https://www.google.com/maps/place/Bandung (left), authors own processing (right)).

Based on the analysis using the ArcGIS 10.3 application, the following results are obtained:

The average proximity from the respondent's house to the Kalbu Palem Park.

\begin{tabular}{|c|c|c|c|c|}
\hline \multicolumn{5}{|c|}{ Average proximity to park (per range coverage classification) (meters) } \\
\hline $\mathbf{0 ~ - ~ 2 0 0 ~}$ & $\mathbf{2 0 0}-\mathbf{4 0 0}$ & $\mathbf{> 4 0 0}-\mathbf{6 0 0}$ & $>\mathbf{6 0 0}-\mathbf{8 0 0}$ & $>\mathbf{8 0 0} \mathbf{- 1 0 0 0}$ \\
\hline 190.17 & 422.28 & 649.7 & 885.28 & 962.42 \\
\hline
\end{tabular}

(Source: authors own processing). 
From the results of the table 2 calculation shows that based on the coverage radius shows only at the coverage radius $>0-200$ meters and coverage radius $>800-1000$ meters, the average location proximity shows the results according to the category of coverage radius to the park that is 190.17 meters and 962.42 meters. In Table 3 below will show an The analysis of Shortest Path Trace (SPT) the suitability of according to the proximity of the location of the house to the park based on the standardization of coverage radius and the perception of security from the community based on the results of the questionnaire (see Fig. 4). While in table 4 shows the use of modes from the community to the location of the park based on coverage categories radius.

Table 3.

Conformity of the average proximity based on the radius of coverage along with the security perception to the Kalbu Palem Park.

\begin{tabular}{|c|c|c|c|}
\hline \multirow{2}{*}{ Coverage Radius (meters) } & \multicolumn{3}{|c|}{ Proximity Analysis (meters) } \\
\cline { 2 - 4 } & + & - & $\begin{array}{c}\text { Security Perception } \\
\text { (SP) }\end{array}$ \\
\hline $0-200$ & 54.03 & 43.94 & 1.98 \\
\hline$>200-400$ & 111.76 & 87.45 & 2.10 \\
\hline$>400-600$ & 137.34 & 61.62 & 2.07 \\
\hline$>600-800$ & 180.81 & 91.45 & 2.21 \\
\hline$>800-1000$ & 222.66 & 173.28 & 1.88 \\
\hline
\end{tabular}

(Source: authors own processing).

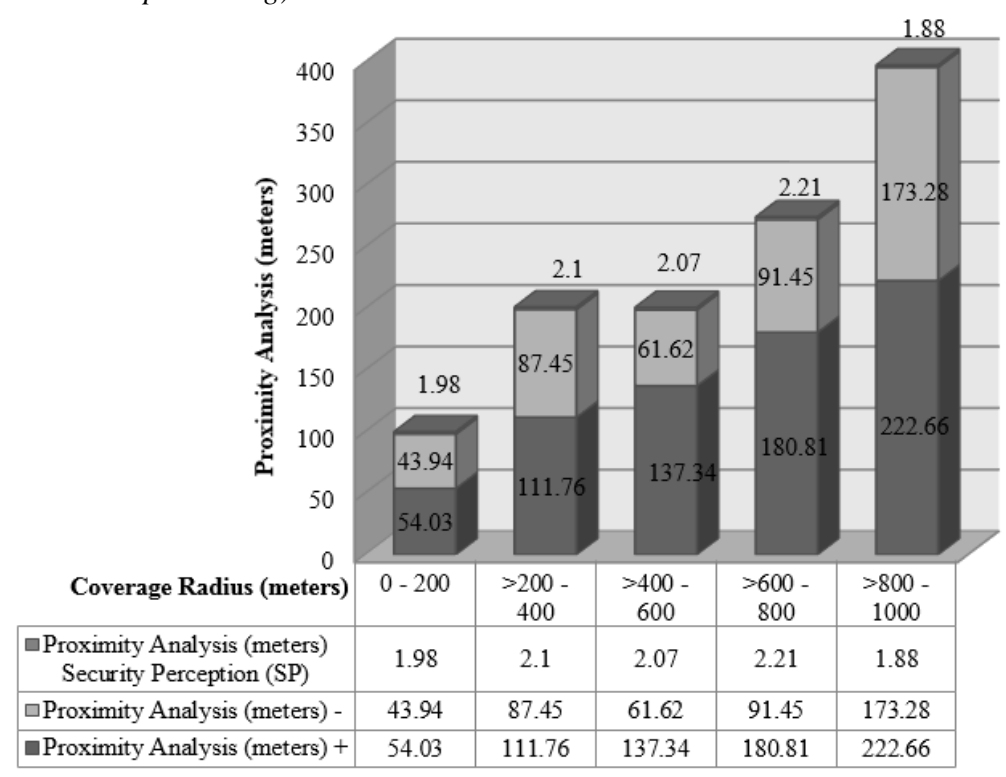

Fig. 4. Conformity of the average proximity based on the radius of coverage along with the security perception to the Kalbu Palem Park.

Information:

Proximity Analysis (+): The average value is based on the difference from the upper limit of the coverage radius with the proximity of the respondent's house to the location of the park. 
Proximity Analysis (-): The average value is based on the difference from the lower limit of the coverage radius with the proximity of the respondent's house to the location of the park.

Security Perception (SP): The average of the results of the answers (based on Likert Scale) of respondents based on security perceptions related to the proximity in encouragement use of park.
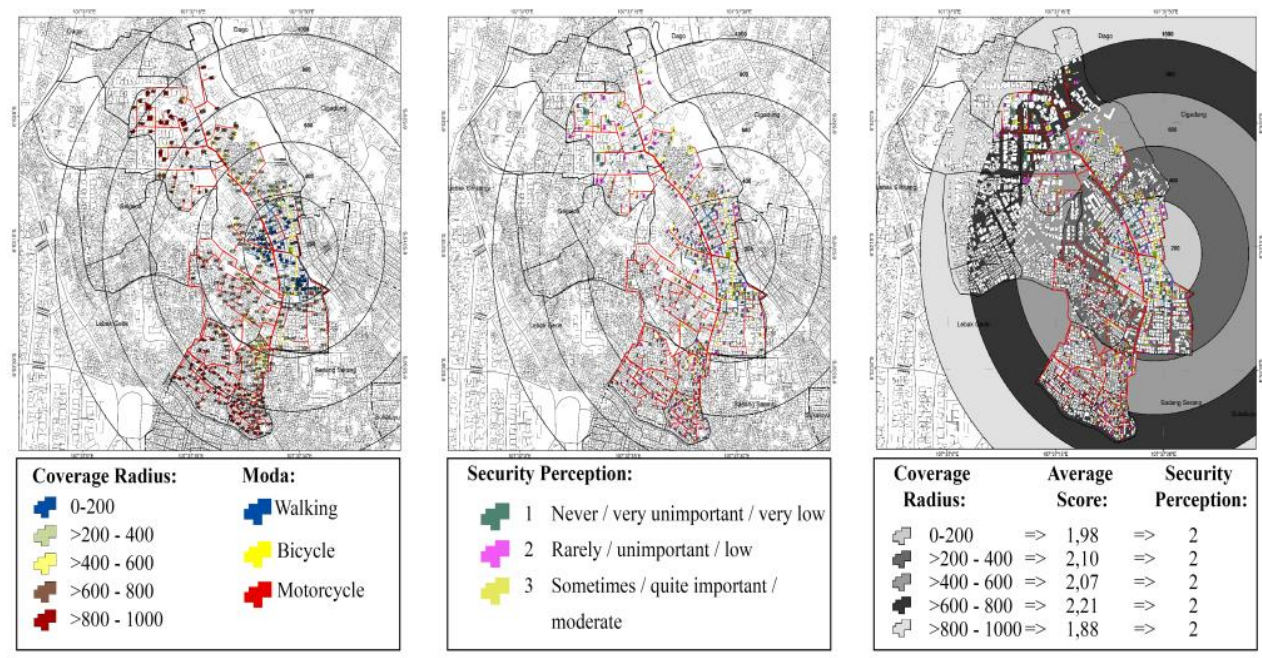

Fig. 5. The result of spatial map overlay (right) according to proximity (left) and security perception (middle) in encouragement of park use (Source: authors own processing).

Based on the proximity of respondents to the park exceeds the average category of existing coverage radius, but the perception of public safety regarding the proximity to the park shows the highest value in the category $>600-800$ meters which is 2.21 (low), with an average perception of community safety based on the proximity to the encouragement to use the park is 2.05 (low category) (see Fig. 5). It means that proximity has a low significance on respondents' safety perceptions of visiting the park. While in table 4 shows the use of modes from the community to the location of the park based on coverage categories radius. In Table 4, the average percentage of modes used by the community to the park mostly using motorcycle $(54.98 \%)$, but in the category of proximity of $0-200$ meters respondents prefer to walk in accessing the location of Kalbu Palem Park.

Table 4.

The use of modes is based on the coverage radius to the Kalbu Palem Park.

\begin{tabular}{|c|c|c|c|c|}
\hline \multirow{2}{*}{$\begin{array}{c}\text { Coverage } \\
(\text { meters) }\end{array}$} & \multicolumn{3}{|c|}{ Modes } & $\begin{array}{c}\text { Frequency mode is } \\
\text { the most commonly } \\
\text { used }\end{array}$ \\
\cline { 2 - 4 } & Walking & Bicycle & Motorcycle & Walking \\
\hline $0-200$ & 47 & 14 & 28 & Motorcycle \\
\hline$>200-400$ & 27 & 28 & 63 & Motorcycle \\
\hline$>400-600$ & 5 & 34 & 45 & Motorcycle \\
\hline$>600-800$ & 1 & 24 & 32 & Motorcycle \\
\hline$>800-1000$ & 0 & 5 & 58 & Motorcycle \\
\hline Total & $\mathbf{8 0}$ & $\mathbf{1 0 5}$ & $\mathbf{2 2 6}$ & \\
\hline Percentage (\%) & $\mathbf{1 9 . 4 6}$ & $\mathbf{2 5 . 5 4}$ & $\mathbf{5 4 . 9 8}$ & \\
\hline
\end{tabular}

(Source: authors own processing) 


\section{CONCLUSIONS}

From the results of research related to the relationship of proximity with the encouragement of the use of parks based on security perceptions, argued some of the views of previous researchers who stated proximity is an important aspect in public space (park) planning where they indicate that the proximity of the park location has a big impact on the community in the use of the park in the future in this research turns out to be a low impact.

Based on the coverage radius shows only at the coverage radius $>0-200$ meters and coverage radius $>800-1000$ meters, the average location proximity shows the results according to the category of coverage radius to the park that is 190.17 meters and 962.42 meters. The results of the calculation based on the mapping do not actually reflect the actual proximity because the existing calculations do not take into account the slope of the land from the study site. In the results of the questionnaire to the community around the park location shows that the perception of community safety regarding the proximity to the park shows the highest value in the category $>600-800$ meters which is 2.21 (low), with an average perception of community safety based on the proximity to the encouragement to use the park is 2.05 (low category). It means that Based on these results, there is a weak link between proximity and park usage based on security perceptions the proximity has a low significance of the respondent's security perception in encouragement of public space use (parks) visiting the park.

\section{ACKNOWLEDGEMENTS}

This research was supported by Regional and Urban Planning Doctoral Study Program, Institute Technology of Bandung. We are very grateful for the Sekeloa urban village government in Bandung city which has given permission to carry out a survey at the research location as well as the participation of the community members in the Sekeloa urban village who have provided their opinions through a questionnaire that has been disseminated. We also thank to the 2 reviewers for their comments on improving the quality of this paper.

\section{REFERENCES}

Annerstedt, M., Östergren, Per-Olof., Björk, J., Grahn, P., Skärbäck, E. \& Währborg, P. (2012) Green qualities in the neighbourhood and mental health - results from a longitudinal cohort study in Southern Sweden, BMC. Public Health, 12 (1), 1-12.

Blobaum, A \& Hunecke, M. (2005) Perceived danger in urban public space the impacts of physical features and personal factors. Environment and Behavior, 37 (4), 465-486.

Byrne, J. \& Wolch, J. (2009) Nature, race, and parks: past research and future directions for geographic research. Progress in Human Geography, 33 (6), 743-765.

Carmona, Heath, Tim., Taner, Oc \& Tiesdell, Steve. (2003) Public places - urban spaces, the dimension of urban design. Architectural Press, Oxford, UK.

Commission for Architecture and the Built Environment. (2005) Start with the park : creating sustainable urban green spaces in areas of housing growth and renewal. CABE, USA.

Creswell, J. (2009) Research design : pendekatan kualitatif, kuantitatif, dan mixed (terj.). Pustaka Pelajar, Yogyakarta. 
Fitri, Husnul, Sundoko., Akbar Roos., Zulkaidi, Denny. \& Argo Teti Armiati. (2018) Perception of terror risk and of the security of counter-terrorism design in public spaces. International Journal of Technology, 9 (3), 491-500.

Fujiki, Kenji, Renard, Florent. (2018) Geographic analysis of post-disaster social impacts on a municipal scale - a case study of a potential major flood in the Paris region (France). Geographia Technica, 13 (2), 31-5.

Gamal, H. E. (2010) Network society: social evolution powered by youth. Global Media Journal Arabian Edition Fall/Winter.

Hanan, Himasari. (2013) Open space as meaningful place for students in itb campus. Procedia- Social and Behavioral Sciences, 85, 208-317.

Handayani U.N, D., Soelistijadi, R., \& Sunardi. (2005) Pemanfaatan Analisis Spasial untuk Pengolahan Data Spasial Sistem Informasi Geografi. Jurnal Dinamik, 10 (2), 108-116.

Holland, Caroline., Clark, Andrew., Katz, Jeanne \& Peace, Sheila. (2007) Social interactions in urban public places. Bristol, Joseph Rowntree Foundation, Policy Press, Open University.

Ilmiajayanti, Freska \& Dewi, D.I, Kusumo (2015) Persepsi pengguna taman tematik kota Bandung terhadap aksesibilitas dan pemanfaatannya. Jurnal Ruang, 1 (1), 21-30.

Low, Setha, M. (2010) On the plaza: The politics of public space and culture. University of Texas Press.

Martinát, Stanislav., Kunc, Josef., Klusáček, Petr., Krejčí, Tomáš., Navrátil, Josef., Vnenková, Jana \& Černík, Jakub. (2015) Spatial relations and perception of brownfields in old industrial region: case study of svinov (Ostrava, Czech Republic). Geographia Technica, 10 (2), 66-77.

McCormack, G. R., Rock, M., Swanson, K., Burton, L.,Massolo, A. (2014) Physical activity patterns in urban neighbourhood parks: insights from a multiple case study. BMC Public Health, 14 (1), $1-13$.

Mowen, J. Andrew \& Confer, J. John. (2003) The relationship between perceptions, proximity, and socio-demographic characteristics upon public use of an urban park "in-fill". Journal of Park and Recreation Administration, 21 (3), 58-74.

Nistor M-M., Rahardjo H., Satyanaga A., Leong E-C., Hao K.Z., Sham A.W.L., Wu H. (2019) GISbased approach to identify the suitable locations for soil sampling in Singapore, Geographia Technica, 14, (1), 103-117.

Pugalis, Lee. (2009) The culture and economics of urban space design: public and professional perceptions. Urban Design International, 14 (4), 215-230.

Roberts, Nina. (2014) The modern urban park : access and programming; where have we been... where shall we go? San Fransisco University.

Sevilla, C.G., A.O. Jesus., G.P. Twila., P.R. Bella \& G.U.Gabriel. (2007) Research methods. Rex Printing Company, Quezon City, Philippines.

Shaftoe, Henry. (2009) Convivial urban space: creating effecive public places. Earthscan, UK and USA.

Soemardiono, Bambang., Rachmawati, Murni., Ardianta, D. Agatha \& Nugroho, Setyo. (2019) Spatial analysis of urban dense area in developing criteria design based on people participation: case study of kembang jepun, Surabaya. Geographia Technica, 14, Special Issue, 13-21.

Sugiyono. (2010) Statistika untuk penelitian. Alfabeta, Bandung. 